\title{
Mengenalkan Jenis Profesi dan Jasa Akuntan pada Mahasiswa Baru dalam Upaya Meneguhkan Minat Studi Akuntansi Syariah dan Menyongsong Era Society 5.0
}

\author{
Arif Zunaidi $^{{ }^{*}}$, Sri Anugerah Natalina², Moh. Ary Laksana ${ }^{3}$ \\ $1^{1 *, 2,3}$ Program Studi Akuntansi Syariah, IAIN Kediri, Jawa Timur \\ Email: ${ }^{*}$ arifzunaidi@iainkediri.ac.id, ${ }^{2}$ srianugerahnatalina@iainkediri.ac.id, ${ }^{3}$ airhiiessetiya@ gmail.com
}

(Naskah masuk: 06 Okt 2021, direvisi: 23 Okt 2021, diterima: 25 Okt 2021)

\begin{abstract}
Abstrak
Era industri 4.0 telah mengubah tatanan hidup manusia menjadi lebih tergantung pada tehnologi. Dunia akuntan pun tak luput akan perubahan, baik secara perangkat atau pun kegiatannnya. Belum selesai tantangan yang harus dihadapi oleh hadirnya era industri 4.0, kini hadir era baru yaitu era society 5.0. Era baru ini tentu masih asing di telinga para mahasiswa baru di lingkungan Fakultas Ekonomi dan Bisnis Islam IAIN Kediri. Ditambah lagi dengan tantangan dan peluangnya yang berdasarkan beberapa sumber berdampak pada hilangnya jenis profesi dan jasa akuntan menyebabkan pemangku kebijakan dalam hal ini adalah pengelola Program Studi Akuntansi Syariah berkewajiban untuk meneguhkan minat para mahasiswa baru bahwa pilihan mereka tidaklah salah. Untuk itu dibutuhkan sebuah kegiatan yang dapat menumbuhkan motivasi dari beberapa kalangan agar para mahasiswa semakin memantapkan pilihan mereka. Kegiatan pengabdian masyarakat ini dilaksanakan secara online dalam bentuk webinar dengan memanfaatkan media zoom meeting ebagai perantaranya. Tujuan dari kegiatan ini adalah memberikan beberapa pengetahuan dan modal dasar untuk belajar dan memantapkan pilihan pada Program Studi Akuntansi Syariah. Ada banyak profesi dan jasa akuntan yang dibutuhkan pada era society 5.0. Semua tergantung keahlian yang dimiliki. Kegiatan ini berhasil memberikan pengetahuan dan memantapkan para mahasiswa baru untuk terus berprestasi dan aktif selama perkulihan sembari menyongsong hadirnya era society 5.0.
\end{abstract}

Kata Kunci: Era society 5.0, era industri 4.0, akuntansi syariah, jasa akuntan, profesi akuntan.

\section{Introducing New Students to Complex Refractive Accounting and Services in an Approach to Boost Enthusiasm in Islamic Accounting Studies and Welcome the Society The 5.0 Era}

\begin{abstract}
Industrialization 4.0 has significantly changed the arrangement of human existence, causing it to be more completely dependent on advanced technologies. Accountants' world is not completely impervious to change, whether in terms of capability or activities. The opportunities presented by the involvement of the industrial era 4.0 have not even been completed; instead, a new era, namely the era of society 5.0, has shown up. This new era is certainly unfamiliar to the ears of incoming students at IAIN Kediri's Faculty of Economics and Islamic Business. Coupled with the challenges and opportunities that, according to multiple sources, have an impact on the loss of the type of profession and accounting services, the officials in this case are the managers of the Islamic Accounting Study Program, who are required to pay attention to new students' attention so that their decisions are not factually inaccurate. As a result, an activity that really can encourage motivation from various organizations is necessary so that students might further stabilize their decisions. This social service activity is done through a webinar via a media video conference as an intermediary. The objective of this assignment is to have some fundamental understanding and equity for studying and making decisions in the Islamic Accounting Study Program. In the society 5.0 era, many occupations, including financial accounting, are considered necessary. It all depends on having good expertise. This operation was successful in delivering awareness and supporting new students to pursue their goals of succeeding and being productive in their studies as society 5.0 strategies can be applied.
\end{abstract}

Keywords: The 5.0 societal era, the 4.0 industrial era, sharia accounting, financial accounting, and the accounting profession. 


\section{PENDAHULUAN}

Pandemi Covid19 telah menyebabkan perubahan cepat dalam aktivitas manusia yang ditandai dengan penggunaan otomatisasi yang dibantu oleh kemajuan tehnologi. Dibandingkan dengan era-era sebelumnya, era industri 4.0 datang lebih cepat karena adanya perubahan sosial yang diakibatkan oleh adanya jaringan internet, dimana manusia dituntut untuk menggunakan fasilitas yang ada agar tetap terkoneksi dan berimprovisasi dalam kegiatan sosial atau pun kegiatan ekonominya.

Era industri 4.0 menyebabkan berkurangnya keterlibatan sumber daya manusia dalam aktivitas karena tergantikan oleh tehnologi informasi. Istilah yang paling mudah untuk menyebut era ini adalah cyber phisical system, mengkolaborasikan cyber dan dunia otomatisasi. Akibatnya, efektivitas dan efisiensi dalam dunia kerja meningkat yang berdampak pula pada kualitas kerja dan biaya produksi.

Secara praktik, ada lima hal yang menyebabkan era industri 4.0 lebih cepat dibandingkan dengan era-era sebelumnya, yaitu: pertama, internet of thing (IoT). Pada konsep ini memanfaatkan jaringan internet dalam banyak aktivitas yang akibatnya minimnya interaksi antar manusia.[1]

Kedua, big data. Sistem ini bekerja dengan mengumpulkan berbagai data yang ada yang kemudian diolah dan dikelola sebagai bagian dari pengambilan keputusan. Ketiga, artificial intellegence (ai). konsep ini menghadirkan sebuah tehnologi komputer atau mesin yang memiliki kecerdasan seperti layaknya manusia dan dapat diatur berdasarkan keinginan manusia. Semakin banyak data yang diperoleh, akan semakin mudah pula dalam pengambilan keputusan karena dapat digunakan dalam memprediksi sebuah fenomena karena semua data telah terekam.[2]

Keempat, cloud computing. Artinya internet dimanfaatkan untuk pengolahan data yang dimanfaatkan manusia untuk saling terhubung dalam jaringan internet dan memiliki hak akses dalam mengolad data dalam cloud. Kelima, addictive manufactoring. Konsep ini dikenal sebagai terobosan penting dalam industri manufaktur karena adanya mesin cetak 3D secara digital. Sehingga mampu menciptakan barang yang tidak mampu dikerjakan oleh perusahaan manufaktur biasa.[3]

Hadirnya era industri 4.0 membawa banyak perubahan, khususnya dalam dunia industri. Munculnya banyak jenis profesi baru, inovasi baru dan membuka lahan bisnis baru yang belum pernah ada sebelumnya. Akibatnya, kebutuhan sumber daya manusia semakin berkurang akibat dari pemanfaatan mesin yang menggantikan manusia.

Belum genap hadirnya era industri 4.0 yang datang lebih cepat dari prediksi sebelumnya, saat ini gaung era society 5.0 menggema di seluruh penjuru bumi sebagai bagian dari tantangan yang dihadapi setelah hadirnya era indusri 4.0. Mahasiswa baru yang notabene sebagai salah satu generasi dari korban pandemi covid19 dituntut untuk dapat menyongsong hadirnya era baru itu dengan berbagai manfaat dan konsekuensinya.
Era society 5.0 diperkenalkan Jepang pada tahun 2019 akibat dari hadirnya era industri 4.0 yang berdampak nyata pada degradasi manusia. Super smart society (Society 5.0) menjadikan manusia sebagi objek dan kompunen penting, tidak sekedar pasive component seperti halnya manusia pada era industri 4.0. Akibatnya, era society 5.0 diharapkan mampu menghasilkan sebuah nilai baru dimana sebuah elaborasi dan kerja sama pada sistem, informasi dan tehnologi mampu meningkatkan kualitas sumber daya manusia sebagai bagian tak terpisahkan dalam sebuah human capital.[4]

Menghadapi era society 5.0, mahasiswa saat ini yang pada saat nanti termasuk bagian dari sumber daya manusia yang turut bersaing dalam persaingan dunia kerja mengharuskan memiliki keahlian dan kemampuan yang dibutuhkan dalam dunia kerja. Kemampuan yang dimaksud adalah kemampuan dalam memecahkan masalah dan bertidak sebagai problem solver bagi diri dan orang lain. Selain itu juga dituntut untuk berfikir kritis, khususnya dalam kehidupan sosial, sehingga akan memunculkan kepekaan sosial dan kemampuan untuk berkreativitas.[5]

Mahasiswa perlu menyiapkan kemampuan dalam menghadapi era sosiety 5.0. Untuk itu diperlukan kesiapan sekaligus berfikir higher order thinking skill (hots) dalam menjawab tantangan yang hadir di depan mata. Kemampuan berfikir ini meminimalisir kesenjangan pola pikir dan orientasi tehnologi, sehingga dengan pola pikir tersebut mampu mengintegrasikan kemampuan daya cipta manusia dan juga tehnologi pada saatnya.[6]

Dunia pendidikan tinggi pun memiliki tanggung jawab dalam menyambut kehadiran era society 5.0. khususnya dalam menyiapkan SDM lulusannya. Oleh karena itu, selain menyiapkan kurikulum yang sesuai dengan kebutuhan jaman, fakultas juga dituntut untuk memberikan informasi kepada mahasiswa tentang peluang dan tantangan pada dunia kerja.

Perkembangan zaman telah menuntut setiap individu untuk melakukan perubahan dan menyesuaiakan dengan perubahan zaman. Tak terkecuali sebuah profesi yang berkaitan dengan dunia akuntansi. Agar dapat diterima oleh pasar dan menjadi pemenang atas persaingan tenaga kerja, seorang akuntan juga turut dituntut karena perannnya dalam era industri 4.0 menuju era society 5.0 adalah mampu Menyediakan insight atas berbagai data, mampu menyajikanya menjadi sebuah data penting, menganalisa, mengecek dan menginterprestasikannya dalam sebuah hasil yang akurat. Tak sekedar turut serta dalam uji kompentensi, namun juga dapat mengolah data dan menguasai soft skill, integritas dan hal-hal lainnya sebagai bagian untuk menjadi akuntan profesional.[7]

Perkembangan era industri 4.0 menuju era 5.0 mengakibatkan perubahan besar dalam susunan kegiatan ekonomi dan profesi. Untuk itu, cara kerja dan praktik akuntan haruslah mengikuti perkembangan demi peningkatan pelayanan ekpansi melalui jaringan dan tehnologi berbasis clod computing.

Sebagai wujud dari pertanggung jawaban prodi untuk memberikan pengalaman belajar yang mampu menghasilkan sebuah lulusan yang mimiliki kapasitas yang bagus, maka 
memberikan kesan dan emosi dalam memotivasi mahasiswa baru untuk belajar dan meneguhkan pilihan mereka pada juruan yang dipilih. Perubahan lingkungan belajar dari tatap muka ke online tentu juga memiliki pengaruh pada pengalaman belajar. Hal ini juga turut mempengaruhi minat dan motivasi mereka dalam belajar.[8]

Sebagai bagian dari meneguhkan minat para mahasiswa baru pada program studi akuntansi syariah, maka program studi Akuntansi Syariah mengadakan acara dalam bentuk webinar dalam upaya untuk mengenalkan jenis profesi dan jasa akuntan pada era society 5.0. Harapannya, setelah mengikuti program ini mahasiswa makin semangat dalam belajar di perguruan tinggi dan meneguhkan hati dalam memilih akuntansi syariah sebagai bagian untuk menyiapkan diri dan meningkatkan keahlian dalam menyongsong era society 5.0 yang penuh dengn tantangan dan peluang.

\section{METODE KEGIATAN}

Untuk mencapai tujuan dalam meneguhkan minat para mahasiwa baru dalam memilih program studi akuntansi syariah dan menyongsong era society 5.0 maka perlu dilakukan beberapa persiapan. Tahapan-tahapan ini dimaksudkan agar tujuan yang hendak dicapai dapat berjalan sesuai rencana program yang telah dibuat. tahapan-tahapan tersebut meliputi:

\section{a. Perencanaan}

Sebuah perencanaan membutuhkan sebuah konsep yang matang. maka tim melakukan beberapa evaluasi tentang kegiatan-kegiatan sebelumnya dan membaca beberapa referensi tentang tema-tema yang update yang berkaitan dengan kebutuhan mahasiwa baru. Pada tahap perencanaan ini Tim menyusun beberapa tema dan alternatifnya, kemudian mendiskusikannya dalam tim kecil untuk memilih tema yang tepat dan menyusun kegiatan acara, mengundang pembicara dan anggarana dananya.

Termasuk dalam proses perencanaan ini adalam menentukan hari dan tanggalnya. Fakultas Ekonomi dan Bisnis Islam di IAIN Kediri memiliki empat program studi, diantaranya : Prodi Ekonomi Syariah, Prodi Perbankan Syariah, Prodi Manajemen Syariah dan Prodi Akuntansi Syariah. Keempat prodi ini juga memiliki program yang sama untuk menyambut mahasiswa barunya.

Agar tidak ada bentrokan jadwal dengan prodi lainnya dan sebagian untuk menyukseskan acaranya, maka dipilih hari Selasa, tanggal 28 September 2021 sebagai kegiatan acaranya.

Sebagain dari perencanaan adalah menentukan para pembicaranya sebagai narasumber pada kegitan ini. Dengan mempertimbangkan kebutuhan dan sebagian untuk memotivasi mahasiswa baru untuk aktif di dunia kampus, maka dipilih tiga narasumber. Pertama, pemilihan narasumber dipilih berdasarkan kriteria yang berasal dari kalangan akademisi. Sehingga beradasarkan pada tim diskusi kecil, dipilih narasumber dari Univeritas Brawijaya Malang yang menjabat sebagai Ketua Program Studi Keuangan dan perbankan, San Rudiyanto.
Kedua, narasumber yang berasal dari alumni Fakultas Ekonomi dan Bisnis Islam yang telah bekerja yang ditunjuk berdasarkan kriteria khususnya yang bekerja sebagai akuntan. Dipilihlah Afika Kusuma Dewi yang saat ini bergabung dalam tim audit bank BTPN cabang Kediri.

Ketiga, narasumber yang berasal dari mahasiswa aktif yang juga bergabung pada Ikatan akuntan Indonesia (IAI) Muda jawa timur, Dwi Ratnasari. Tujuan dari pemilihan narasumber yang masih aktif sebagai mahasiswa ini adalah untuk memotivasi para mahasiswa baru agar aktif dalam berorganisasi, khususnya organisasi yang sesuai dengan bidangnya, yaitu akuntansi.

Setelah daftar narasumber telah dipilih dan memberikan surat permohonan untuk menjadi narasumbernya, maka selanjutnya adalah membuat flayer kegiatan yang nantinya akan dibagikan kepada para calon peserta.

Dalam dunia pemasaran, flayer termasuk dalam kategori media yang dapat digunakan dalam kegiatan promosi. Flayer ini juga memiliki fungsi lain, yaitu sebagai media yang memuat informasi yang ditujukan kepada publik terkait penyelenggaraan sebuah acara. Tujuannya, agar publik mengetahui dan tertarik dalam kegiatan yang dibagikan dalam flayer tersebut.[9]

Terkait dengan penyelenggaraan sebuah kegiatan, flayer harus memuat beberapa hal, antara lain: penyelenggara kegiatan, termasuk logo intansi penyelenggara. Topik yang menjadi bahasan utama, para narasumber dan moderatornya. untuk pemateri dan narasumbernya haruslah dilengkapi dengan keterangan singkat jabatannya sebaga daya tariknya. Flayer juga harus memuat moda pelaksanaannya, apakah online ataukah offline. Termasuk dalam moda pelaksanaan ini juga memuat informasi meeting id dan passwordnya jika menggunakan media online meeting. Flayer juga memuat link pendaftaran para peserta, media sosial dan nama kontak yang bisa dihubungi.

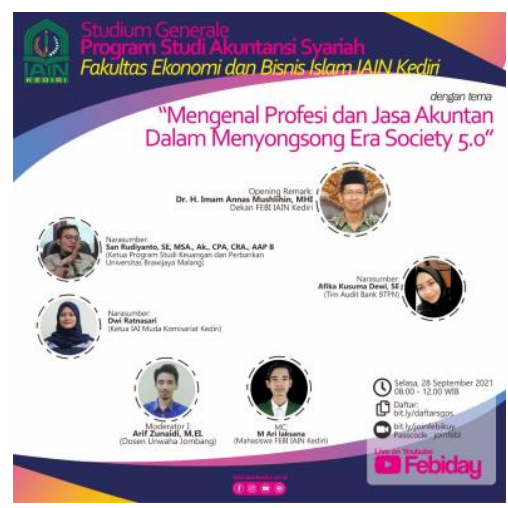

Gambar 1. Flayer yang digunakan sebagai media informasi

Selain pemilihan narasumber dan flayer, kegiatan ini juga memilih media zoom meeting sebagai bagian dari kegiatan ini. Fasilitas ini telah dimiliki oleh Fakultas dan dapat dimanfaatkan untuk kegiatan-kegiatan yang sifatnya online.

Selain itu, untuk mengantisipasi lonjakan peserta dan sebagai bagian untuk mendokumentasikan kegiatan secara 
online, kegiatn ini juga disiarkan secara langsung melalui kanal Youtube yang dimiliki Fakultas, Febiday.

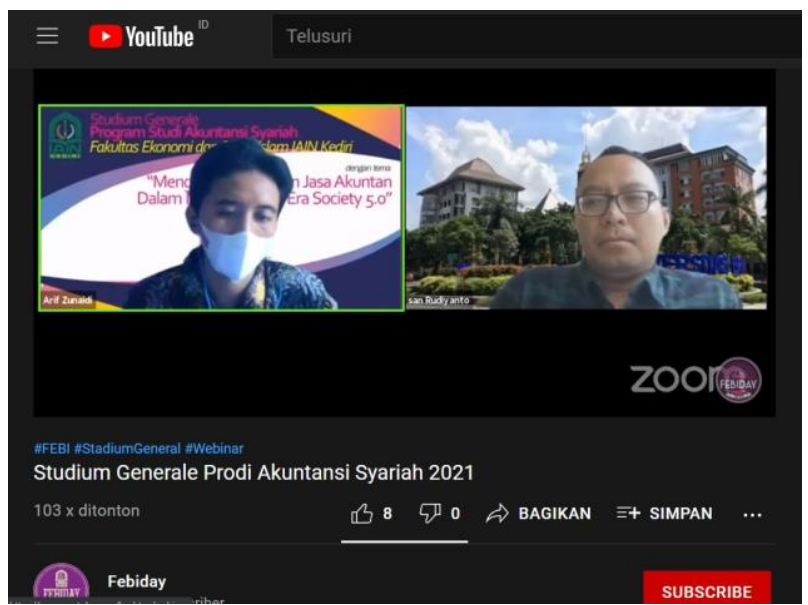

Gambar 2. Kanal youtube yang dimanfaatkan untuk dokumentasi secara online.

\section{b. Pelaksanaan kegiatan}

Demi kelancaran sebuah kegiatan, khususnya dalam sebuah acara webinar yang mendatangkan narasumber dari beberapa tempat, maka perlu diperiapkan materi yang siap untuk dibagikan kepada para peserta. Maka untuk memperlancar kegiatan presentasi para narasumber, materi sudah diterima oleh panitia dan siap didistribusikan kepada para peserta dan untuk ditampilkan pada waktu presentasinya.

Kesuksesan sebuah acara webinar ditentukan oleh kesiapan panitia dan para narasumbernya. Untuk itu diperlukan tim solid dalam mengelola media dan jalannya acara demi kesuksesan sebuah kegiatan yang diikuti oleh peserta yang banyak.

Dimulai dari pemilihan pembawa acara, pembaca ayat suci, pemimpin do'a, dan moderatornya. Sebelum acara, para petugas dilakukan breafing terlebih dahulu, dilakukan sebelum acara dibuka secara umum untuk mengetes apakah suara dan kamera sudah termapasng dengan sempurna.

Narasumber juga dibagi menjadi tiga sesi, dimana masing-masing naraumber menyampaikan selama 40 menit. Selesai penyampaian materi, dilanjutkan dengan sesi Tanya jawab yang dipandu oleh moderator.

c. evaluasi

keberhasilan sebuah kegiatan dinyatakan sukses jika seluruh kegiatan berjalan lancer, tujuan kegiatan yang ingin disampaiakan atas kegiatan ini dapat diterima oleh para peserta. Untuk itu, evaluasi diperlukan sebagai bagian dari penilaian atas keseluruhan kegiatan mulai dari tema dan narasumbernya. Evaluasi ini juga diperlukan sebagai masukan untuk kegiatan-kegiatan selanjutnya.

\section{PELAKSANAAN KEGIATAN}

Sesuai dengan tema, kegiatan ini memlih tema "Mengenal Profesi dan Jasa Akuntan dalam Menyosong era Sosiety 5.0". Kegiatannya dilakukan dilaksanakan pada Selasa, 28
September 2021. Dilakanakan secara virtual dengan memanfaatkan aplikasi Zoom meeting dan disiarkan secara langsung via kanal youtube, Febiday.

Kegiatan ini diikuti oleh kurang lebih 200 peserta, dengan rincian: peserta utamanya adalah mahasiswa baru program studi Akuntansi Syariah yang berjumlah 138 mahasiwa, 38 mahasiswa semester 3 dan para peserta umum yang memiliki minat dalam bidang akuntansi. Kegiatan dilaksanakan secara online dengan durasi sekitar 4 jam.

Kegiatan diawali dengan pendaftaran ulang para peserta dan memasuki ruang zoom meeting. Panitia pelaksana dan pembawa acara mengkoordinir dan mengkondisikan para peserta untuk mengikuti aturan kegiatan demi kelancaran kegiatan webinar.

Acara dibuka oleh dekan fakultas, Bpk. Dr. Imam Annas Muslihin, MHI. Dimana pada kesempatan tersebut berterima kasih atas para narasumber yang telah sudi mengisi pada kegiatan stadium general prodi akuntani syariah.

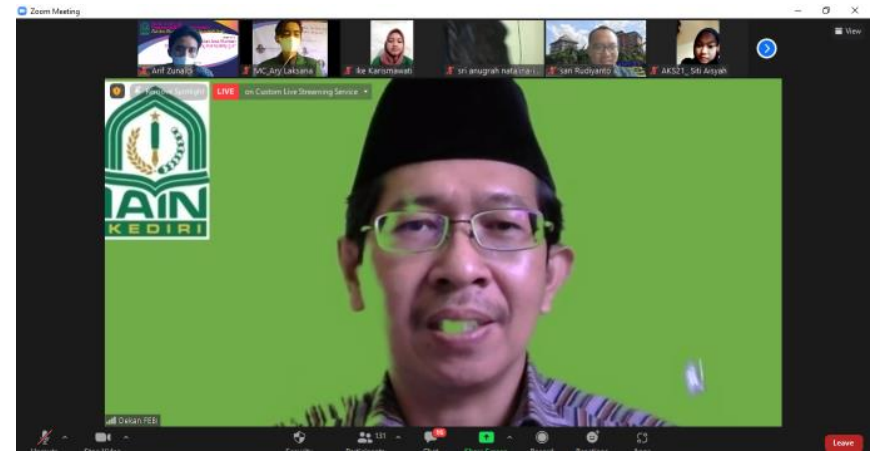

Gambar 3. Sambutan \& pembukaan oleh Dekan FEBI

Acara inti dipandu oleh moderator dengan menghadirkan tiga pembicara sebagai narasumbernya. Narasumber pertama, menyampakaikan tema mengenal profesi dan jasa akuntan dalam menyongsong era society 5.0. Dalam penyampaiaan materi, narasumber memberikan keterangan perjalanan dan lompatan sejarah sebelum hadirnya era society 5.0 dan inti ari dari revolusi-revolusi yang pernah terjadi.

Selain itu, narasumber pertama juga menjelaskan banyak hal tentang tantangan dan peluang yang dihadapi akan hadirnya era society 5.0. Pun banyaknya pekerjaan-pekerjaan baru yang bermunculan meski beberapa mulai hilang dtinggalkan oleh para pelakunya karena sudah mulai berkurangnya permintaan pasar.

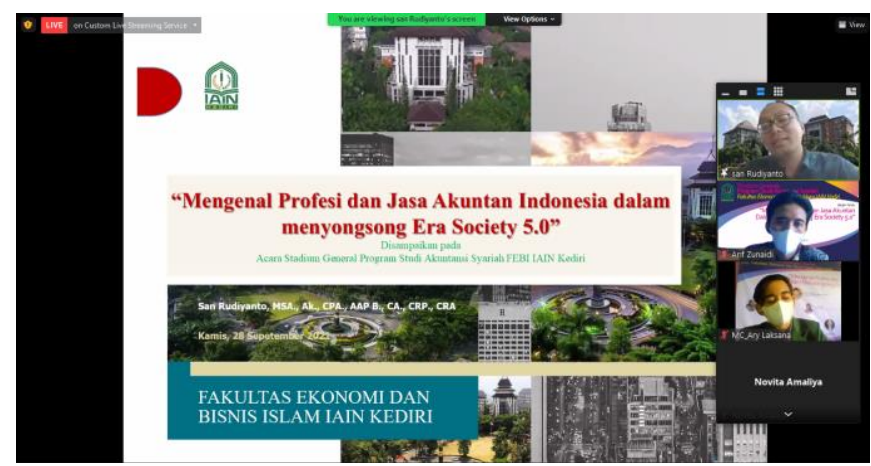




\section{Gambar 4. Tampilan slide presentasi narasumber pertama}

Pada kesempatan tersebut juga disampaikan tentang beberapa hal yang dapat dilakukan oleh mahasiswa akuntansi syariah untuk mempersiapkan dan menyambut era baru, era society 5.0 .

Narasumber kedua memfokuskan diri pada pengalaman dan hal-hal yang dapat dilakukan untuk dapat diterima di dunia kerja yang berkaitan dengan akuntan. Untuk dapat diterima pada bidang kerja yang memiliki sedikit lapangan kerja tentu saja membutuhkan metode khusus agar dapat diterima pada dunia kerja. Salah satunya dengan memperkuat keahlian dan mindsite individunya.

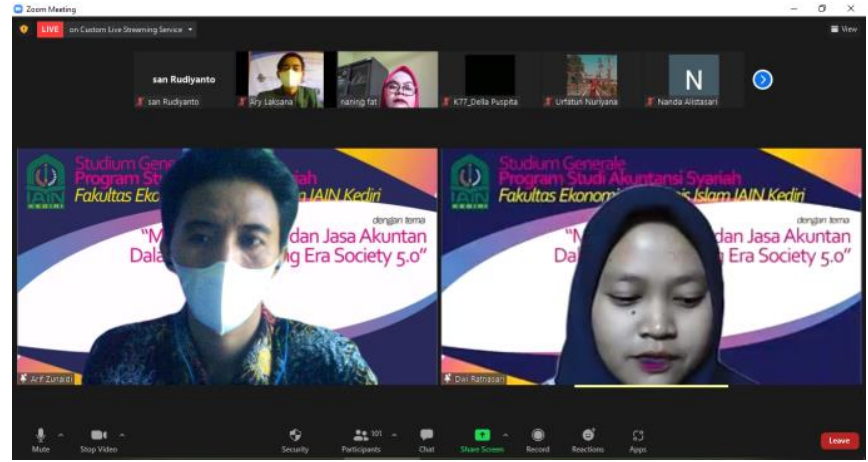

Gambar 5. Penyampaian materi oleh narasumber ketiga.

Narasumber ketiga memfokuskan materinya tentang pentingnya keaktifan dan berorganiasi sesuai dengan bidang keahlian, dalam hal ini bidang akuntansi syariah. Narasumber yang juga termasuk dalam ketua pengurus IAI Muda Karisidenan Kediri mengajak para mahasiswa untuk aktiv dan berprestasi slama perkulaihan. Karena dengan aktif dan berprestasi inilah yang akan menjdaikan calon lulusan unggul sesuai bidang dan siap untuk menyongsong dunia kerja yang penuh dengan persainagan.

Sesi webinar ditutup dengan tanya jawab, dimana selama presentasi oleh para pematerinya para peserta dapat bertanya dan menyampaiakan beberapa pertanyaan kepada narasumbernya. Sehingga pada sesi tanya jawab para pemateri dapat menjawab setiap pertanyaan yang masuk dari peserta.

Selama kegiatan berlangsung, tidak ada hambatan apapun yang menyebabkan terhambatnya kegiatan webinar ini. Permasalahan justru muncul jelang 1 hari pelaksanaan kegiatan. Dimana pemateri kedua, yang eharusnya menghadirkan alumni Fakultas Ekonomi dan Bisnis Islam yang bekerja di audit bank BTPN mengundurkan diri karena ada tugas mendadak dari kantor cabang ke kantor pusat di Surabaya. Otomatis panitia penyelenggara harus mencarikan pengganti agar narasumber tetap terisi.

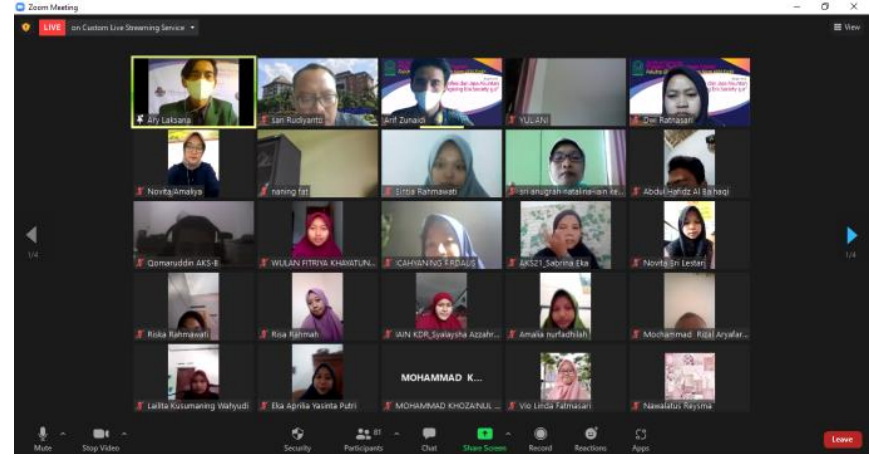

Gambar 6. Tampilan peserta webinar.

Bersyukur sekali pengganti dapat ditemukan langsung, dimana narasumbernya masih satu almamater, alumni Fakultas Ekonomi dan Bisnis Islam yang bekerja pada konsultan pajak dan akuntan publik di kota Kediri.

Dengan persiapan seadanya dan berkas materi yang baru dapat diserahkan sejam sebelum acara berlangsung menjadikan ketua pelaksana dan moderatornya sedikit sangsi, apakah akan efektif atau tidak sesi penyampaiannya.

Meski demikian, ternyata acara masih tetap berlangsung sesuai jadwal dan mendapat apreasiasi dari banyak pihak karena memberi banyak pilihan narasumber. Sehingga mahasiswa baru dapat memiliki informasi lengkap tentang tugas dan tujuan mereka mengambil jurusan akuntansi syariah dan perannya dalam menyongsong era society 5.0.

\section{KESIMPULAN}

Secara keseluruhan acara dapat berlangsung dengan lancar dan dapat diterima oleh para mahasiswa baru. Penyampaian materi juga interaktif, sehingga mudah dipahami. Sebagai tindak lanjutnya, alangkah baiknya jika ada program lanjutan yang bertujuan pada studi-studi keahlian dalam bidang akuntansi syariah. Sehingga ketika menghadapi persaingan dalam dunia kerja, mahasiswa sudah memiliki bekal memadai.

\section{REFERENSI}

[1] M. Merlina and A. Nuraini, "Analisis Persepsi Dosen Akuntansi Dan Mahasiswa Akuntansi Mengenai Peranan Akuntan Di Era Revolusi Industri 4.0," JASPT (Jurnal Anal. Sist. Pendidik. Tinggi Indones., vol. 4, no. 2, p. 149, 2020, doi: 10.36339/jaspt.v4i2.347.

[2] I. F. Cahyadi, "Peranan Sistem Informasi Akuntansi dan Tantangan Profesi Akuntan di Era Revolusi Industri 4.0 (Sebuah Studi Fenomenologi)," AKTSAR J. Akunt. Syariah, vol. 2, no. 1, p. 69, 2019, doi: 10.21043/aktsar.v2i1.5497.

[3] Y. Tata Rini, "Mengurai Peta Jalan Akuntansi Era Industri 4.0," Ref. J. Ilmu Manaj. dan Akunt., vol. 7, no. 1, p. 58, 2019, doi: 10.33366/ref.v7i1.1339.

[4] Y. Puspita, Y. Fitriani, S. Astuti, and S. Novianti, "Selamat Tinggal Revolusi Industri 4.0, Selamat Datang Revolusi Industri 5.0," Pros. Semin. Nas. 
Pendidik. Progr. Pascasarj. Univ. Pgri Palembang, pp. 122-130, 2020, [Online]. Available: https://jurnal.univpgripalembang.ac.id/index.php/Prosidingpps/article/view/3 $794 / 3565$.

[5] E. Setiawan, G. M. Muhammad, and ..., "Analisis Kemampuan Pemecahan Masalah Mahasiswa pada Mata Kuliah Teori Bilangan,” ... J. Pendidik. ..., vol. 10, pp. 61-72, 2021, [Online]. Available: https://journal.institutpendidikan.ac.id/index.php/mosha rafa/article/view/mv10n6.

[6] L. Asmaul Husna and A. Syukur, "Meningkatkan Higher Order Thinking Skills Melalui Penerapan Kemampuan Berpikir Historis pada Mahasiswa Pendidikan Sejarah," Pros. Semin. Nas. Pascasarj.
Univ. Negeri Jakarta, pp. 22-31, 2020.

[7] Kuniawan and T. Badriatin, "Optimalisasi Peran Akuntan Pada Era 4.0," J. Character Educ. Soc., vol. 2, no. 2, pp. 79-84, 2019.

[8] A. Zunaidi, R. Rahmah, and S. Salsabila, "Meningkatkan motivasi akademis selama pandemi pada mahasiswa baru fakultas febi iain kediri," vol. 2, no. 3, pp. 337-344, 2021.

[9] Y. Adharani, R. Latifah, P. Meilina, and N. Rosanti, "Pelatihan Pembuatan Flyer Promosi untuk Menunjang Digital Marketing pada Klinik Kesehatan," Semin. Nas. Pengabdi. Masy. LPPM UMJ, pp. 93-102, 2020. 